International Journal of Publication and Social Studies

$\operatorname{ISSN}(e): 2520-4491$

$\operatorname{ISSN}(p): 2520-4483$

DOI: $10.184 .88 /$ journal.135.2021.62.72.81

Vol. 6, No. 2, 72-81.

(C) 2021 AESS Publications. All Rights Reserved.

URL: www.aessweb.com

\title{
THE ROLE AND IMPACT OF AGRICULTURAL MACHINERY SERVICE PROVIDER FOR RURAL COMMUNITY DEVELOPMENT CASE IN INDONESIA
}

\author{
Kodrad Winarno ${ }^{1+}$ \\ Amie Sulastiyah ${ }^{2}$ \\ Muhamad Rusliyadi ${ }^{3}$
}

\author{
'Indonesian Centre for Agricultural Education Agricultural Extension and \\ Human Resource Development Agency, Ministry of Agriculture, Indonesia. \\ Email:wiwindkln@gmail.com \\ ${ }^{2, s}$ Polytechnic of Agricultural Development rogyakarta-Magelang, \\ Agricultural Extension and Human Resource Development Agency, Ministry \\ of Agriculture, Indonesia.
}

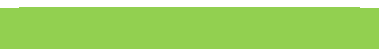

Article History

Received: 2 July 2021

Revised: 30 July 2021

Accepted: 20 August 2021

Published: 16 September 2021

\section{Keywords}

Agribusiness

AMSP

Organization

Economy

Technical

Agricultural machinery

Community developmen

The role and impact.

\section{ABSTRACT}

Agricultural machinery plays a strategic role in achieving Indonesia's agricultural development goals. It is considered capable of increasing agricultural production and productivity through managing cultivation, harvest and post-harvest activities. The government has facilitated farmers with agricultural machinery through farmer groups and joint-farmer groups by encouraging them to form Agricultural Machinery Services Provider (AMSP). The purpose of this research is to describe the agribusiness management of AMSP, in terms of organizational, technical and economic aspects. This research was conducted from June 2017 to October 2017 in four districts, namely Bantul, Sleman, Gunung Kidul and Kulon Progo. Purposive sampling was used as a sampling method in this research. There were 32 respondents; 12 from AMSP, 16 from farmers groups, 4 private agricultural machinery service providers. The data analysis used was descriptive and qualitative data analysis. This research concluded that management of AMSP from an organizational perspective in the 4 districts is compatible with the Permentan Nomor 252018 guidelines regarding growth and development of AMSP. From the technical aspect, most of the operational agricultural machinery is 2 -wheeled and 4-wheeled tractors. From the economic aspect, Earnings are distributed based on 40:60 ratio where AMSP earns 40\% and the operator earns $60 \%$. In relation to the cost of land cultivation, AMSP can earn between RP. 600.000,-Rp. 800.000,- and the operator can earn Rp.900.000,-- Rp. 1.200.000,-.

Contribution/ Originality: The paper's primary contribution is finding that Agricultural Service Provider has a significance role and impact of the farmer welfare of community development.

\section{INTRODUCTION}

The government is constantly making efforts to encourage farmers to increase production and productivity of agricultural commodities, especially crops in the agricultural production system. One of the efforts made is facilitating farmers with agricultural machinery (“alat mesin pertanian” - agricultural machinery). By providing this aid through farmer groups (“kelompok tani" - farmer groups) and joint farmer groups ("gabungan kelompok tani”), the government endeavours to reach self-sufficiency in target crops especially rice, corn, soybean and horticulture (Ditjen, 2017). Agricultural machinery is considered to play an important role in increasing agricultural production and productivity, especially food crops in Indonesia. Agricultural machinery is considered capable of increasing 
agricultural production and productivity through managing cultivation, harvest and post-harvest activities (Kementerian Pertanian, 2008). Furthermore, agricultural machinery can overcome the issue of lack of manpower in the agricultural sector (Ditjen, 2017)

Since 1998, the Ministry of Agriculture has made efforts to increase farmers' utilization of agricultural machinery. AMSP (Agricultural machinery services provider) is a program that was launched to manage government aided agricultural machinery, AMSP is a profit-oriented institution at the farmer level managed by farmer groups. AMSP was introduced in 13 provinces: Aceh, North Sumatra, Riau, Jambi, Lampung, West Java, Central Java, Yogyakarta, East Java, West Kalimantan, South Kalimantan, South Sulawesi and West Nusa Tenggara.

AMSP's function is to carry out economic activities in the form of providing services including cultivation management which covers preparing and processing farmland, irrigation, planting, maintaining, protecting including fire control. Furthermore, AMSP also provides services for harvest and post-harvest activities like harvesting, threshing, drying, and milling. It also provides services for processing of agricultural products including encouraging product development in order to increase added value and marketability, market expansion, competitiveness and improving farmer welfare (Ditjen, 2014).

Since its launch in 1998, many AMSP have been formed throughout Indonesia. Based on regional reports, the number of AMSP institutions have reached 7,570 units in 2006 and almost doubled in 2012, with 12,044 units (Unadi, Alihamsyah, \& Budiarti, 2014).

In relation to the above, in 2014 DIY (Daerah Istimewa Yogyakarta) had 191 AMSP units in 4 districts namely Bantul, Sleman, GunungKidul and Kulon Progo (Dinas, 2014). With agricultural machinery aid provided by the government, AMSP has provided services to farmer communities to support rice cultivation processes, secondary crops and horticulture. AMSP is generally managed by farmer groups. Management of AMSP is usually agreed upon by farmer groups, but sometimes it is not how an organization is expected to be managed. This is due to the insufficient ownership of agricultural machinery as provided in organizational guidelines

Cost of operations of agricultural machinery has been insufficiently measured according to information from several groups because agricultural machinery aid from the government is not commercialized, it is lent to those in need which causes the agricultural machinery to be inefficiently utilized and hindering its development. Some farmer groups do not belong to organizations like AMSP and there are some who do belong to an organization, but the organization is not run efficiently, recording transactions and AMSP activities is still considered complicated.

Additionally, simultaneous planting patterns and uncoordinated group behaviour means farmers have not reached the stage where they work together to improve commercial businesses. This has caused AMSP performance to be suboptimal and in order to fulfil needs of farmers, AMSP services are carried out from the results of decision-making by certain officers and the results run according to farmers' needs.

With the above conditions, the agricultural machinery service processes by AMSP in supporting the cultivation of rice, corn, secondary crops and horticulture is still running and is able to meet the needs of the farming community. However, without structured management can the AMSP develop, especially in the DIY region? This research aims to describe the organizational, technical and economic aspects of agribusiness management of AMSP operating in Yogyakarta.

According to the Minister of Agriculture's Regulation No.25 / Permentan / PL.130 / 5 / 2008, the purpose of developing AMSP is to encourage and motivate the development and progress of the performance of AMSP institutions in order to improve and optimize the utilization of agricultural machinery from an organizational, technical and economic perspective as well as supporting aspects aimed at to become a professional AMSP. UJPA groups are generally managed by the farming community. AMSP is no different from the organization of farmer groups because the managers are usually part of farmer groups. 
The conditions and development of farmer organizations practices according to Syahyuti (2011) is that almost every development to villages introduces one new organization because organization is a component that can become an agent of change. However, this approach tends to be inappropriate. There are seven mistakes that have been found, namely: 1). Organizations that are built are limited to strengthen horizontal ties, 2). Organizations are formed to the purpose of distributing aid, facilitating control of program implementation and mobilization, 3). Each program/project forms one new organization, 4). Organizational structures and culture are built relatively uniform, 5). Organizational development always starts with creating an organizational structure and filling it with management; there is no learning process, 6). Providing material assistance (tractors, threshers or cash) is considered to have strengthened the capacity and performance of the organization, while the management capabilities of the management and members are not given enough attention, 7). The introduction of new organizations has damaged existing local organizations, including damaging existing horizontal relationships, because the project is sectoral and discontinuous.

Management of AMSP encompasses administration, control, maintenance and leadership. According to Hasibuan (1984), management comes from the word to manage which means to control. Controlling is done through a process and arranged according to the order of management functions. Therefore, management is a process to realize the desired goals. Management is the science and art of regulating the process of utilizing human and other resources actively and efficiently to reach a certain goal. Furthermore, Usman (2011) states that management in the broadest sense is planning, organizing, directing and controlling organizational resources to achieve goals effectively and efficiently. Whereas in the narrow sense, the management of an organization includes program planning, program implementation, leadership, supervision or evaluation and information systems. Correspondingly, Torang (2014) states that management is very important for every individual or group activity in an organization to achieve desired goals. Management is process oriented which means that management requires human resources, knowledge, skills and abilities so that activities are more effective and can result in actions that can achieve success. Therefore, there cannot be a successful organization without good management.

Success in implementing management requires the leadership of a manager. Torang (2014) proposed that management is the ability or skill to achieve a goal through others' actions. Therefore, for management in an organization to easily achieve its objectives effectively, efficiently and rationally, an organization's leader must be able to carry out management functions. One of the functions of management is organizing.

The programme introduced should be focused on empowering rural communities to enable them to carry out their economic activities. Such empowerment should be complemented by other cross-sectoral programmes that should be widely practised throughout the entire country (Rusliyadi, Jamil, Mohd, \& Kumalasari, 2019)

Organizing is a process of distributing work and tasks and coordinating them to reach the goals of the organization. The definition of organizing according to Torang (2014) is to arrange functions that are considered necessary for the achievement of objectives and are an indication of authority and responsibility given to individuals assigned to carry out management functions. Furthermore, Torang (2014) emphasizes that organizing is allocating necessary tasks and delegating required authority. There are four activities that are required to be done in organizing, namely a). Dividing and grouping work, b) Determining the work to be done, c) Delegation of authority, d) Providing workspace and supporting technology. Additionally, Torang (2014) revealed six ways to organize:
a. Know the goals of the organization.
b. Arrange sequentially the tasks to be completed.
c. Group activities according to their respective fields.
d. Describe clearly the tasks that must be carried out.
e. Determine persons who will carry out the tasks.
f. Delegate authority to individuals who have been appointed to carry out tasks or duties. 
Organization in AMSP is necessary because it will help individuals both as a leader and member, and other parties requiring the services provided. According to Stephen and Mary (1999), organizations are social units that are coordinated with relatively easily identifiable boundaries and continuously work to achieve common goals. Organization is a system that consists of subsystems or sub parts that are interrelated in carrying out activities, it can also be understood that organization is a group of small parts that are formed into one form and have activities that are structured and planned according to the determined goals (Sutarto, 1991). According to Sondang (1980), organization as a system is an open system where the limits are flexible and considers environmental factors as inputs. The organization is always susceptible and is always adapting with changes in that occur in external environmental factors. External environmental factors include a. Technology, b. Socio-politics, c. Residents, d. Socio-Culture, and many others that are constantly changing.

According to the Minister of Agriculture's regulation No. 25 / Permentan / PL.130 / 5 / 2008 regarding growth and development of AMSP, organization in AMSP is like any other organization. However, size of the organization is determined by the amount of agricultural machinery owned by AMSP. The different capability levels of AMSP are defined as follows: a) Beginner AMSP, b) Developing AMSP, c) Professional AMSP. Beginner AMSP are a group of agricultural machinery service providers that have yet to develop in terms of optimizing management of agricultural machinery because they have one to four units of agricultural machinery and one to two types of agricultural machinery. Developing AMSP are a group of agricultural machinery service providers that have five to nine agricultural machinery units, three to four different types of agricultural machinery and have a complete organizational structure. Professional AMSP are a group of agricultural machinery service providers that have optimized management of agricultural machinery and have more than 10 agricultural machinery units and more than five types of agricultural machinery.

In the regulation stated above, AMSP having ownership of more than five units and three types of agricultural machinery is recommended to have a complete organizational structure. However, if AMSP has less than five units and three types of agricultural machinery a written organizational structure is required even though there is only a manager. In practice, the performance is already organized. Additionally, AMSP classification is also determined by considering organizational, technical, economic and supporting aspects. Organizational aspects cover the legality and organizational structure, including complete and accurate bookkeeping records. Technical aspects include agricultural machinery type, quantity, condition, storage and maintenance and repair centers. Economic aspects cover addition of agricultural machinery quantity, source of funding and increasing the number of customers and expanding service area. Supporting aspects include how to obtain AMSP services, AMSP operational service schedules and the number of farmers who are members of farmer groups who require AMSP services.

\section{METHODOLOGY}

This research was conducted from June 2017 to October 2017 in four districts, namely Bantul, Sleman, GunungKidul and Kulon Progo. Both primary and secondary data was used in this research. Primary data is information collected directly from respondents. The method used to obtain primary data is through interviews. Secondary data are collected from documents such as bookkeeping records of farmer groups and AMSP, government regulatory documents, activity reports and others.

The sampling method used in this research is purposive sampling. According to Bungin (2006) purposive sampling is used in research that prioritizes the research objectives in determining research sample. Questionnaires were given to AMSP managers to distribute to the appropriate respondents. There were 32 respondents in each district selected to be part of the population sample; 12 from AMSP, 16 farmer groups, 4 agricultural machinery service providers.

This research is a descriptive qualitative study; it aims to understand what is experienced by the subject of the research holistically through describing it in a scientific context (Bungin, 2006). Qualitative data analysis was used 
as a method to analyze results. The process of analyzing data was done continuously, starting with reviewing all data available from various sources such as interviews, observations from field reports and other documents until a conclusion was drawn up.

To avoid erroneous data, the validity of data was tested in the following ways:

a. Data collection was continuous on the same research subjects.

b. Other sources could be held accountable for, and if necessary.

c. Checking was done by research subjects.

The researchers referred to several stages according to Ulber (2012) in conducting data analysis:

a. Collecting information via interviews with compatible key informants then direct field observation to support the research to ensure that data source is as expected.

b. Data reduction, which is a process of selecting, simplifying, transforming raw data from field reports to select which information is relevant to the research.

c. Data display, which is displaying collective information such as narratives, network graphs, tables and charts with the intention to simplify and condense it without reducing its contents by way of presenting it in the form of tables and descriptions.

The final step is conclusion drawing or verification, which seeks meaning from explanatory patterns, possible configurations, causal flows and propositions. The drawing conclusions is done carefully and continuously verified with field reports so that data can be tested for validity.

\section{RESULTS AND DISCUSSION}

There have been programs to encourage development activity in AMSPs in DIY Province. Some AMSP included in the program are: 1) AMSP Argorejo, Desa Argorejo, Kecamatan Sedayu, Bantul District, 2) AMSP Sumber Makmur, Dusun Dinginan, Desa Sumberejo, Kecamatan Prambanan, Sleman District, 3) AMSP Tirtosari Desa Karangrejek, Kecamatan Wonosari, Gunungkidul District, dan 4) AMSP Jati Makmur, Desa Jatirejo, Kecamatan Lendah, Kulon Progo District. Prior to the AMSP development activities, especially in areas producing rice, corn and secondary crops in low-lying areas, most farmers had already been using agricultural machinery, however the acetone was not managed by special units like AMSP. Nevertheless, farmer groups have been already familiar and have already applied usage of agricultural machinery such as two-wheeled tractors, power threshers and rice milling units (RMU). The sources of these machines were either from government or private aid, the RMU in particular, which is mobile and provides service from place to place.

Since the introduction of AMSP in the four districts mentioned above, management of agricultural machinery in farmer groups has been carried out by the AMSP. The results of the research have shown that AMSP's management activities had followed the guidelines provided in the Minister of Agriculture's Regulation No. 25 / Permentan / PL.130 / 5 / 2008 regarding Growth and Development of AMSP. Management of AMSP has fulfilled the organizational, technical and economic aspects covered in the regulation guidelines.

Organizational operations in the four districts can be summarized in the figure below: a. AMSP Argorejo, Bantul District

The AMSP Organizational diagram in general is like in the Figure 1. Most the structure in the head of AMSP is The the manager as the leader. The manager has treasury and secretary for helping daily activity of manager. The manager also has four structured on the job description, i.e. the business development and marketing section, maintenance section, warehouse unit house and also operator unit.

b. AMSP Sumber Makmur, Sleman District 


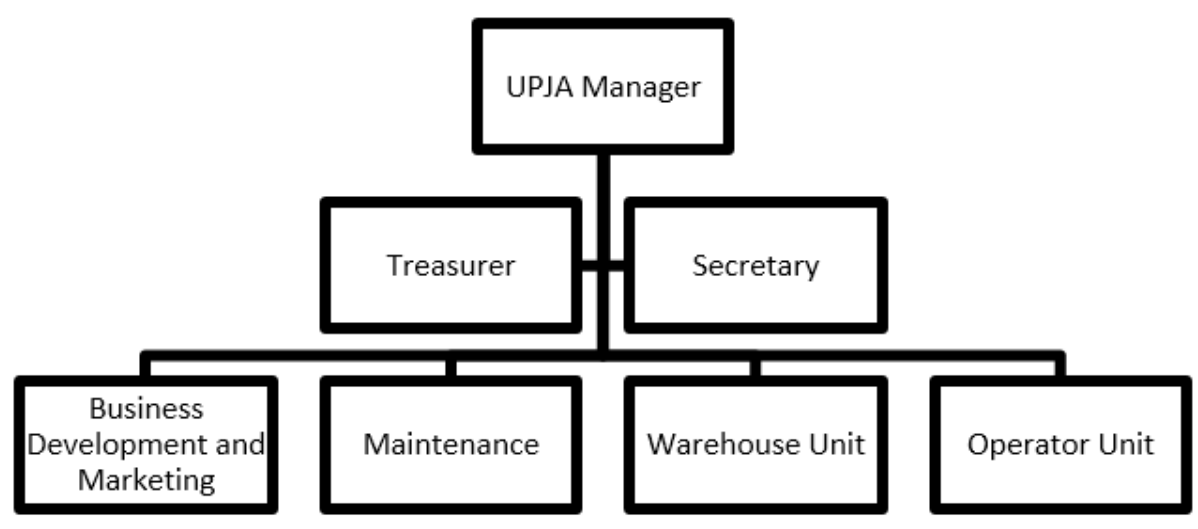

Figure-1. The General Organizational Diagram of AMSP Argorejo, Bantul District.

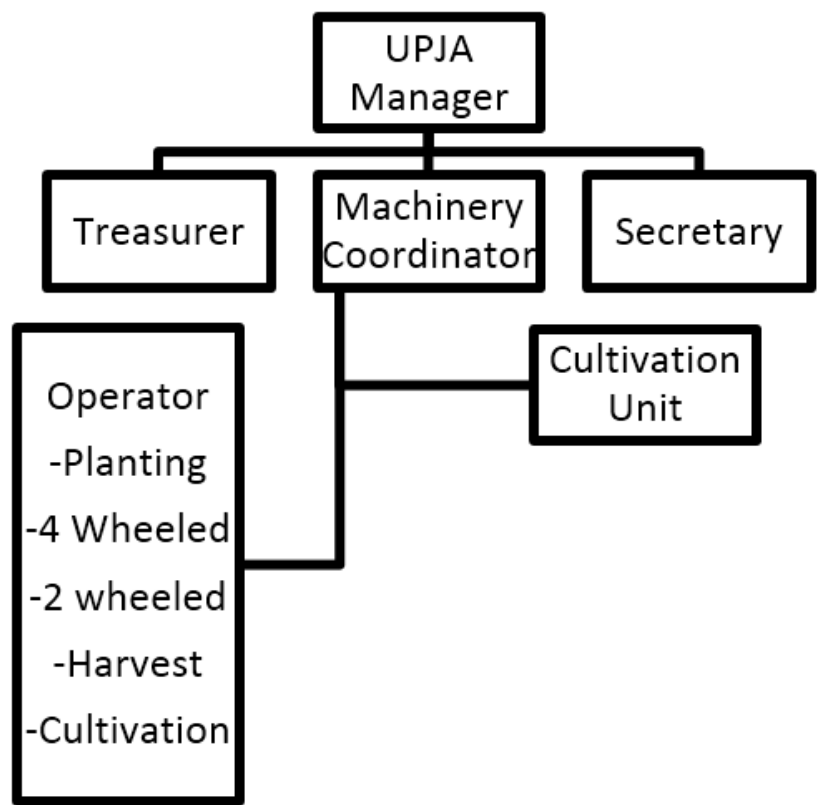

Figure-2. The Organizational Diagram of AMSP Sumber Makmur, Sleman District.

The AMSP Sumber makmur Sleman district has different diagram for the structured diagram of the organization show in Figure 2. The Manager has three people in charge for the UKA with the treasurer, machinery coordinator and secretary and the machinery coordinator have another section like operator different machinery and cultivation unit.

c. AMSP Tirtosari, Gunungkidul District

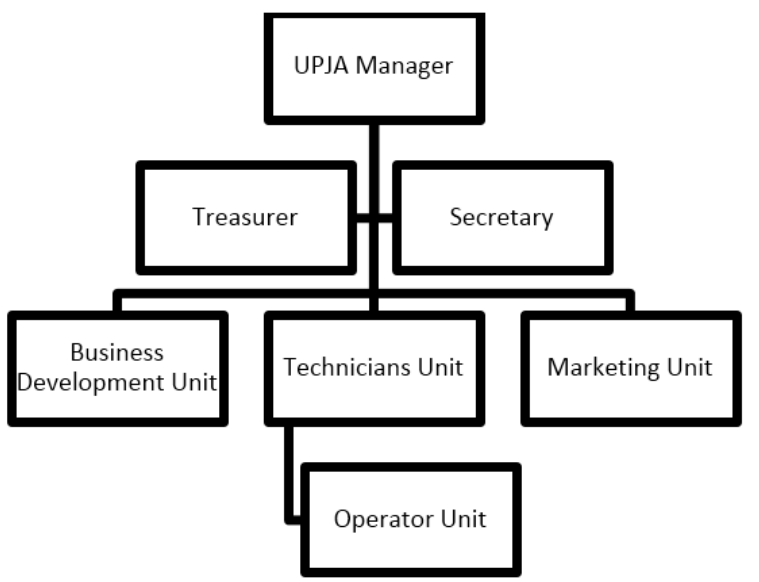

Figure-3. The Organizational Diagram of AMSP Tirtosari, Gunungkidul District. 
Figure 3 shown the AMSP manager in the Tirtosari Gunung Kidul district has almost same but different and par of them separately the business development unit section and marketing unit section. They make simple organizational with the technician unit section in helping by operator unit.

d. AMSP Jati Makmur, Kulon Progo District

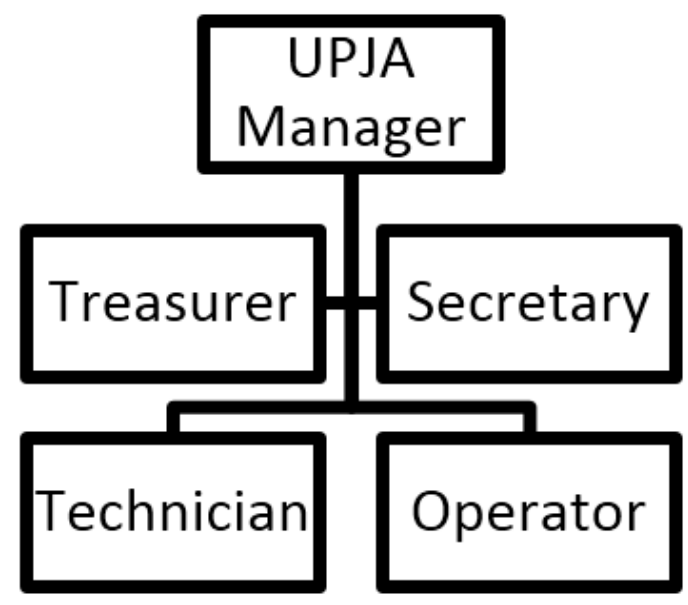

Figure-4. The Organizational Diagram of AMSP Jati Makmur, Kulon Progo District.

The AMSP Jati makmur at Kulon program district has a simple organizational diagram since the manager is has main section into just four people in charge or section in charge shown in Figure 4. The manager directly has treasure, secretary, technician and operator for helping the operational production of the organization on the daily basis.

In the four districts, each farmer group has an AMSP and the AMSP is managed by farmer groups in the region. The organizational structure is as follows shown in Figure 5:

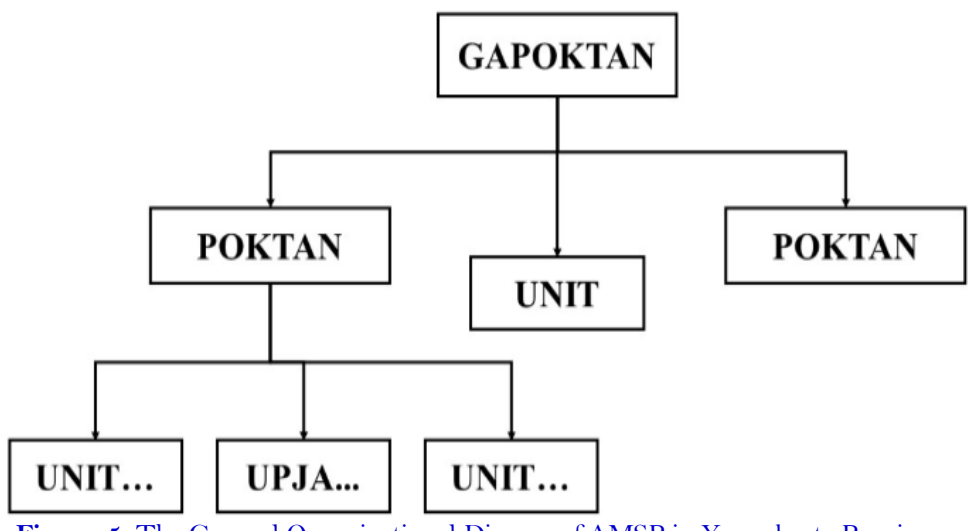

Figure-5. The General Organizational Diagam of AMSP in Yogyakarta Province .

From the organizational structure AMSP is a farmer-based organization that plays a role in agricultural business development in the rural level. It is important for AMSP to develop to support rural economic development. Business organizations have the main purpose, whether written or not to profit. Successful AMSP that are managed by farmer groups have distributed jobs and tasks in accordance with roles and responsibilities.

AMSP in the four districts were generally managed by farmer groups and led by a manager. Each AMSP had a complete organizational structure, with important positions such as treasurer, secretary, operators and technicians. In terms of administration, every AMSP had bookkeeping records such as general cashbooks, consumer request service records and operator control records. Moreover, management reports of each AMSP were also reported to local government officials by AMSP management, signed and verified by AMSP manager and farmer group leader. 
AMSPs were not the only providers of agricultural machinery services, there were also private and individually owned agricultural machinery. In terms of business management, individual agricultural machinery service providers act as both owner and operator. The number of agricultural machinery owned varies between one and two units, with the majority owning two wheeled tractors. The individual agricultural machinery service providers had the ability to cultivate an average area of 10 ha per season.

Beside the organizational aspects, technical aspects are also important in AMSP. AMSP in the four districts had at least 11 agricultural machinery units per AMSP. AMSP Tirtosari, Gunungkidul district had 11 units and AMSP Jati Makmur, Kulon Progo district had the most with 21 units owned. The types of agricultural machinery owned by AMSP were: two-wheeled tractor, four-wheeled tractor, trans planter, combine harvester and water pump as presented in Table 1. All agricultural machinery owned by AMSP comes from government assistance, grants, or farmer groups. As for private agricultural machinery service providers, their agricultural machinery is privately owned and sourced.

Table-1. AMSP Agricultural machinery ownership in D.I.Y Yogyakarta

\begin{tabular}{|c|c|c|c|c|c|}
\hline \multirow[t]{2}{*}{ No. } & \multirow[t]{2}{*}{$\begin{array}{l}\text { Agricultural } \\
\text { machinery }\end{array}$} & \multicolumn{4}{|c|}{ No. of agricultural machinery in AMSP (unit) } \\
\hline & & Agrorejo & Tirtosari & Sumber Makmur & Jati Mamur \\
\hline 1 & Two-wheeled Tractor & 5 & 4 & 5 & 7 \\
\hline 2 & Four-wheeled Tractor & 3 & 3 & 2 & 3 \\
\hline 3 & Transplanter & 3 & $\mathrm{O}$ & 4 & 4 \\
\hline 4 & Combine Harvester & 2 & $\mathrm{O}$ & 1 & $\mathrm{O}$ \\
\hline 5 & Water Pump & 5 & 2 & $\mathrm{O}$ & 5 \\
\hline 6 & Power Thresher & $\mathrm{O}$ & 1 & $\mathrm{O}$ & 1 \\
\hline 7 & Paddy Mower & $\mathrm{O}$ & 1 & $\mathrm{O}$ & $\mathrm{O}$ \\
\hline 8 & Rice Milling Unit & $\mathrm{O}$ & $\mathrm{O}$ & $\mathrm{O}$ & 1 \\
\hline \multicolumn{2}{|c|}{ Total } & 18 & 11 & 12 & 21 \\
\hline
\end{tabular}

AMSP stored agricultural machinery inadequate warehouses or garages. Agricultural machinery was maintained and serviced regularly. Even though there was a technician in the organizational structure of AMSP, special technicians still need to be called in to handle more complex repairs, so services from outside parties was still required.

AMSP is profit-oriented so development can be seen from the economic and supporting aspects. AMSP activities generally do not run all day, however, they are busier just before the growing season, especially approaching the first growing season, which is November - February, second growing season March - July and third growing season July - October. With the amount of agricultural machinery owned by AMSP, the services provided include tilling, planting and harvesting. Service coverage is not limited to the location of AMSP, AMSP also serves requests for land cultivation and harvest services for nonmembers and outsiders. Most services requested outside of the service coverage are land cultivation using two-wheeled, particularly for paddy fields. This is due to the fact that land ownership in DIY is relatively small, between $500-1000 \mathrm{~m}^{2}$. For example, in Lendah, Kulon Progo District and Wonosari, Gunungkidul District, two-wheeled tractors serve many areas outside the coverage area because the tractors are suitable for those lands. Four-wheeled tractors are used a lot for dry land, such as in Gunungkidul district

However, this research found that trans planters and combine harvesters could only develop in AMSP Sumber Makmur, Prambanan, Sleman district. This was because AMSP management educated farmers on the use of the machines for about a year, so many farmers were able to use the machines. This was not applied in other AMSPs such as AMSP Jati Makmur Tirtosari and AMSP Agrorejo. Trans planters and combine harvesters were not received well with the local community. This was due to the local culture embedded in the community where for they relied on their physical strength for growing and harvesting activities, and the role of social support was still 
greatly appreciated by the community and family/kinship structure was still very close-knit. With such a phenomenon, there were at least two reasons used as excuses for farmers to avoid agricultural machinery, a) harvest labor was easily found in the area, and b) a relatively small harvest area. Thus, Indo Jarwo trans planter or rice trans planter were not popular in Lendah or Wonosari because of the availability of farm labor. Similarly, acceptance of new technology for harvest was not always accepted by farmers. Because of this, AMSP Jati Makmur and Tirto Sari made use of pedal thresher more than combine harvester.

Agricultural machinery leasing operations by AMSP lasted approximately 72 days in two seasons, with an average area of $30 \mathrm{ha}$ /year. While in one season, agricultural machinery leasing operations lasted from 20-30 days with an average area of 10-20 ha/season. Earnings are distributed based on a 40:60 ratio, AMSP earns 40\% and the operator earns $60 \%$. Cost of tillage of two wheeled tractors per hectare varies between RP. 1.500.000,- to Rp. 2.000.000,-. So AMSP can earn between Rp. 600.000,-- Rp. 800.000,- and the operator can earn Rp. 900.000,-Rp. 1.200.000,- specifically for the cost of land cultivation using a two-wheeled tractor.

Similar planting patterns in several areas, caused AMSP to be integrated automatically, for example tillage activity is done at the same time in different areas. This activity runs simultaneously between 20-30 days and caused lack of competitiveness between agricultural machinery service providers, both private organizations and AMSP because in the beginning of growing season, the demand for tilling activities is high and service is needed from both AMSP and private agricultural machinery service providers.

\section{CONCLUSION}

1. The Role of AMSP from an organizational aspect: Organizational structure of AMSP in four districts studied in D.I. Yogyakarta is written and complete with relevant administrative documents, in accordance with the guidelines in Permentan No. 25 / Permentan / PL.130 / 5 / 2008. Each AMSP has a complete structure with positions such as managers, secretaries, treasurers, operators and technicians.

2. The Role of AMSP from a technical aspect: Agricultural machinery ownership in AMSP is between 11-21 units with an average of 5 different types of agricultural machinery. Most of agricultural machinery operating in AMSP are two-wheeled tractors and four-wheeled tractors, while other agricultural machinery still have room for development. 3. The Impact of Economic aspect of AMSP: Agricultural machinery leasing operations are mostly active in the beginning of growing season, which is 20-30 days covering an area of between 10-20 ha/season. The cost of tillage per hectare varies between Rp. 1.500.000,-- Rp. 2.000.000,- with earnings distributed based on a 40:60 ratio where AMSP earns 40\% (Rp. 600.000,-- Rp. 800.000,-) and the operator earns 60\% (Rp. 900.000,-- Rp. $1.200 .000,-)$.

Funding: This study received no specific financial support.

Competing Interests: The authors declare that they have no competing interests.

Acknowledgement: All authors contributed equally to the conception and design of the study.

\section{REFERENCES}

Bungin, B. (2006). Qualitative research in communications, economics, public policy, and other social sciences. Jakarta: Kencana Prenada Media Group.

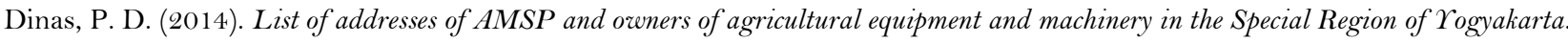
Yogyakarta: DIY Province.: Department of Agriculture.

Ditjen, P. (2014). Technical guidelines for the development and development of machineries services business (AMSP). Jakarta: Directorate of Agricultural Equipment and Machinery, Directorate General of PSP, Ministry of Agriculture.

Ditjen, P. (2017). Guidelines for the implementation of procurement and distribution of agricultural tools and machinery for the 2017 State Budget. Jakarta: Directorate General of Agricultural Infrastructure and Facilities, Ministry of Agriculture.

Hasibuan, M. H. P. (1984). Basic management, understanding and problems. Jakarta: Mount Agung. 
Kementerian Pertanian. (2008). Guidelines for the growth and development of services for agricultural equipment and machinery services. Agriculture Ministry.

Rusliyadi., M., Jamil, A., B, Mohd, \& Kumalasari, R. T. (2019). Analysis of household food security policy: case of food security village programme, Indonesia. Asian Journal of Agriculture and Rural Development, 9(1), 19-32.

Sondang, P. S. (1980). Administrative philosophy. Jakarta: Mount Agung.

Stephen, P. R., \& Mary, C. (1999). Management. Jakarta: PT Prenhallindo.

Sutarto. (1991). Organizational basics. Yogyakarta: Gadjah Mada University Press.

Syahyuti. (2011). It's easy, easy it's hard to organize Farmers. Yogyakarta: IB Press.

Torang, S. (2014). Organization \& management: Alphabet. Bandung.

Ulber, S. (2012). Social research methodology. Bandung: PT Refika Aditama.

Unadi, A., Alihamsyah, T., \& Budiarti, U. (2014). Policy on custom hiring of agricultural machinery in Indonesia. CSAM Policy Brief, Issue No.4, December 2014.

Usman, H. (2011). Management. Educational theory, practice, and research. Jakarta: Earth Literature. 